\title{
Does the Choice of the Growth Potential Classification Affect the Non-surgical Treatment of the Adolescent Idiopathic Scoliosis?
}

\section{Büyüme Potansiyelini Değerlendiren Sınıflandırma Seçimi Cerrahi Dıșı Tedavi Edilen Adölosan İdiyopatik Skolyozluların Tedavisini Etkiler mi?}

\author{
(D) Ahmet Onur Akpolat1, (D) Onur Gültekin1, (D) Bekir Eray Kılınç1, (D) Ahmet Kocabıyık1, (D) Erkan Akgün2, \\ (1) Esin Derin Çiçek3, (1) Mehmet Bülent Balioğlu1 \\ IUniversity of Health Sciences Turkey, Fatih Sultan Mehmet Training and Research Hospital, Clinic of Orthopaedics Surgery and Traumatology, İstanbul, Turkey \\ 2Pursaklar Goverment Hospital, Ankara, Turkey \\ 3University of Health Sciences Turkey, Fatih Sultan Mehmet Training and Research Hospital, Clinic of Radiology, İstanbul, Turkey
}

\begin{abstract}
Objective: This study aimed to determine the progression parameters effect for miscorrelation between the Risser sign and the Sanders classification and the accuracy of the determined level of the skeletal maturation in patients with adolescent idiopathic scoliosis (AIS).

Method: Patients with AIS who were followed up with non-surgical treatment between March 2018 and August 2020 were included in the study. The parameters taken into consideration were age, sex, weight, height, body mass index percentile, menarche status in females, Risser sign and Sanders classifications stages, major Cobb angle, location of the apex of the major curve, and correlation of the Risser sign toward the Sanders classification.

Results: In total, 205 [126 (75.9\%) females and 76 (24.1\%) males] participants were included in the study. The rate of incorrect staging was $17.3 \%$ for the Risser sign toward the Sanders classification. Females were at a higher risk than males $(p<0.05)$. Patients who did not have their first menarche had a higher risk of miscorrelation for the Risser sign and Sanders classification $(p<0.05)$. Interobserver correlations were determined as A substantial correlation for the Risser sign and almost perfect correlation for Sanders classification (Risser $K=0.76$, Sanders $K=0.93$ ).
\end{abstract}

Conclusion: Miscorrelation of the two major growth potential classification systems should be considered to plan better non-surgical treatment. Keywords: Adolescent idiopathic scoliosis, growth potential, risser sign, sanders classification, correlation

ÖZ

Amaç: Bu çalıșmanın amacı, adölosan idiyopatik skolyoz (AiS) hastalarında Risser ișareti ile Sanders sınıflandırması arasındaki uyumsuzluğun ilerleme parametrelerine olan etkisini ve iskelet olgunlaşma düzeyinin doğruluğunu belirlemektir.

Yöntem: Çalışmaya 2018 Mart ile 2020 Ağustos tarihleri arasında cerrahi dışı takip edilen Ais'li hastalar dahil edildi. Değerlendirme parametreleri yaş, cinsiyet, kilo, boy, vücut kitle indeksi, kadınlar için menarj durumu, Risser İșareti ve Sanders sınıflamasındaki evresi, majör cobb açıSı, majör eğriliğin lokalizasyonu ve Risser ișareti ile Sanders sınıflandırması arasındaki korelasyondur.

Bulgular: Çalıșmaya 205 [126 (\%75,9) kadın, 76 (\%24,1) erkek] katılımcı dahil edildi. Risser İșareti ile Sanders sınıflamasın arasında ki korelasyona uymayan hasta oranı \%17,3, olarak saptandı. Kadınlarda ve adet görmemiş kișilerde sınıflandırmalar arasında uyușmazlık oranının daha yüksek düzeyde olduğu saptandı $(p<0,05)$. Gözlemciler arası korelasyon Risser İșareti için yüksek, Sander sınıflaması için neredeyse mükemmel olarak saptandı (Risser $\mathrm{K}=0,76$, Sanders $K=0,93)$

Cite as: Akpolat AO, Gültekin 0, Kılınç BE, Kocabıyık A, Akgün E, Çiçek ED, Balioğlu MB. Does the Choice of the Growth Potential Classification Affect The Non-surgical Treatment of the Adolescent Idiopathic Scoliosis?. IKSSSTD 2021;13(2):123-8

E-mail: onurakpolat@hotmail.com ORCID ID: orcid.org/0000-0001-7773-5476

${ }^{\odot}$ Copyright 2021 by the İstanbul Kanuni Sultan Süleyman Training and Research Hospital / Medical Journal of Istanbul Kanuni Sultan Suleyman published by Galenos Publishing House.

๑Telif Hakkı 2021 İstanbul Kanuni Sultan Süleyman Eğitim ve Araștırma Hastanesi / Istanbul Kanuni Sultan Süleyman Tıp Dergisi, Galenos Yayınevi tarafından basılmıștr. 
Sonuç: Cerrahi dıșı tedavi daha iyi planlamak için iki majör büyüme potansiyel sınfflama sistemin uyumsuzlukları dikkate alınmalıdır.

Anahtar kelimeler: Adölesan idiyopatik skolyoz, büyüme potansiyeli, risser işareti, sanders sinflaması, korelasyon

\section{INTRODUCTION}

There is a close relationship between the growth potential and curvature progression in adolescent idiopathic scoliosis (AIS) (1). Therefore, it is crucial to determine the growth potential, especially in planning the treatment of AIS $(2,3)$. Skeletal maturation classifications were prepared based on ossification centers ${ }^{(4-6)}$ to determine the growth potential. The most popular systems to assess the growth potential are the Risser sign and Sanders classifications ${ }^{(5,6)}$. The Risser sign evaluates the development of the ossification center of the iliac crest apophysis in five stages ${ }^{(5)}$. By contrast, Sanders classification divides it into the eight phases according to the development of ossification centers in the metacarpals and phalanges ${ }^{(6)}$.

In the literature, the miscorrelation between the Risser sign and Sanders classification patients with AIS was reported in a study only ${ }^{(7)}$. However, in that study, the other parameters of progression in patients with AIS were not evaluated (7).

Our hypothesis is the miscorrelation of the two-classification system may result in a false prediction of the growth potential of AIS to plan the correct treatment. These parameters should be taken into consideration to predict the curve progression.

The purpose of this study was to determine the progression parameters effect for miscorrelation between the Risser sign and the Sanders classification, the interobserver reliability of both classifications, and the accuracy of determining the level of skeletal maturation in patients with AIS that planned for the treatment.

\section{METHOD}

This retrospective and the single-center study were performed at Orthopedics and Traumatology clinic between March 2018 and August 2020. It was approved by the institutional review board (IRB number: 2019/4408) and was performed incongruent with the ethical principles of the Declaration of Helsinki. After approval of the IRB, informed consent was obtained from the guardians of all participants.

The study included patients with AIS aged 10-16 years who were within the limits of non-surgical treatment. The exclusion criteria of the study were history of the previous spine or hip surgery, congenital or syndromic concomitant disease, dental braces, non-idiopathic scoliosis, presence of malignancy or history of malignancy, presence of a metabolic or endocrinological disease, previous pelvic and hand injury, accompanying kyphosis deformity, and the time between scoliosis and hand radiography being longer than 4 weeks.

Age, sex, weight, height, body mass index (BMI) percentile (< 18.5, 18-24.9, and $\geq 25$ ), menarche status in females (none, last 12 months, and $>12$ months), major Cobb angle, location of the apex of the major curve (thoracic, thoracolumbar junction, or lumbar), and correlation of Risser sign toward the Sanders classification of the patients were evaluated. The Risser-Sanders correlation scale developed by Vira et al. ${ }^{(8)}$ was used to determine a false stage (Table 1) (Figure $1 A$, $B$, Figure 2A, B).

In the present study, the Risser sign and Sanders classification stages and major Cobb angles were determined by a senior author (> 25 years of specialized experience), a radiologist specialized in musculoskeletal conditions ( $>15$ years of specialized experience), an orthopedics and traumatology surgeon (> 5 years of experience), and a fellowship-trained spine surgeon (> 7 years of specialized experience).

The recorded evaluation parameters and the data obtained from the measurements were evaluated for statistical significance. In addition, the correlation and miscorrelation between the two-classification systems were further analyzed statistically.

\section{Statistical Analysis}

Descriptive statistics were presented with mean \pm standard deviation values. The Kappa test was conducted to examine the consistency of the evaluation levels of four different evaluators in the study (0.01-0.20 as slight correlation, 0.21-0.40 as fair correlation, $0.41-0.60$ as moderate correlation, $0.61-0.80$ as substantial correlation, and 0.811.00 as almost perfect correlation). The chi-square and t-test were performed to examine the differences in patient characteristics according to the correlation level. In addition, repeated analysis of variance was used to analyze the evaluations of the evaluators among themselves. $P$ values of $<0.05$ were considered significant. SPSS version 25.0 was used for analysis. 


\begin{tabular}{|l|l|l|l|}
\hline Table 1. Correlation of sanders & and risser stage during phases of bone growth \\
\hline Sanders stage & Radiographic features & Risser stage & Radiographic features \\
\hline Juvenile slow (1) & Digital epiphyses are not covered & 0 & No ossification of the apophysis \\
\hline Preadolescent slow (2) & All digital epiphyses are covered & 0 & No ossification of the apophysis \\
\hline Adolescent rapid (early) (3) & $\begin{array}{l}\text { Most digits are capped. 2nd-5 } \mathrm{MC} \\
\text { epiphyses are wider than metaphyses }\end{array}$ & 0 & $\begin{array}{l}\text { Triradiate cartilage open (peak height } \\
\text { velocity) }\end{array}$ \\
\hline Adolescent rapid (late) (4) & $\begin{array}{l}\text { Any of distal phalangeal physes are } \\
\text { clearly beginning to close }\end{array}$ & 0 & $\begin{array}{l}\text { Triradiate cartilage remains (open growth } \\
\text { plates in the long bones) }\end{array}$ \\
\hline Adolescent steady (early) (5) & $\begin{array}{l}\text { All distal phalangeal physes are } \\
\text { closed, while others are open }\end{array}$ & 0 & $\begin{array}{l}\text { Triradiate cartilage closed (menarche in } \\
\text { female patients) }\end{array}$ \\
\hline Adolescent steady (late) (6) & $\begin{array}{l}\text { Middle or proximal phalangeal } \\
\text { physes are closing }\end{array}$ & $\geq 1$ & $\begin{array}{l}\text { Ossification of the iliac apophysis ranges } \\
\text { from 25\% to 75\% }\end{array}$ \\
\hline Early mature (7) & $\begin{array}{l}\text { Only distal radial physis is open. MC } \\
\text { physeal scars may be present }\end{array}$ & 4 & $\begin{array}{l}100 \% \text { ossification of the iliac wing, with no } \\
\text { fusion to iliac crest }\end{array}$ \\
\hline Mature (8) & $\begin{array}{l}\text { Distal radial physis is completely } \\
\text { closed }\end{array}$ & 5 & $\begin{array}{l}\text { Fusion of the iliac apophysis to the iliac crest } \\
\text { (cessation of growth) }\end{array}$ \\
\hline
\end{tabular}
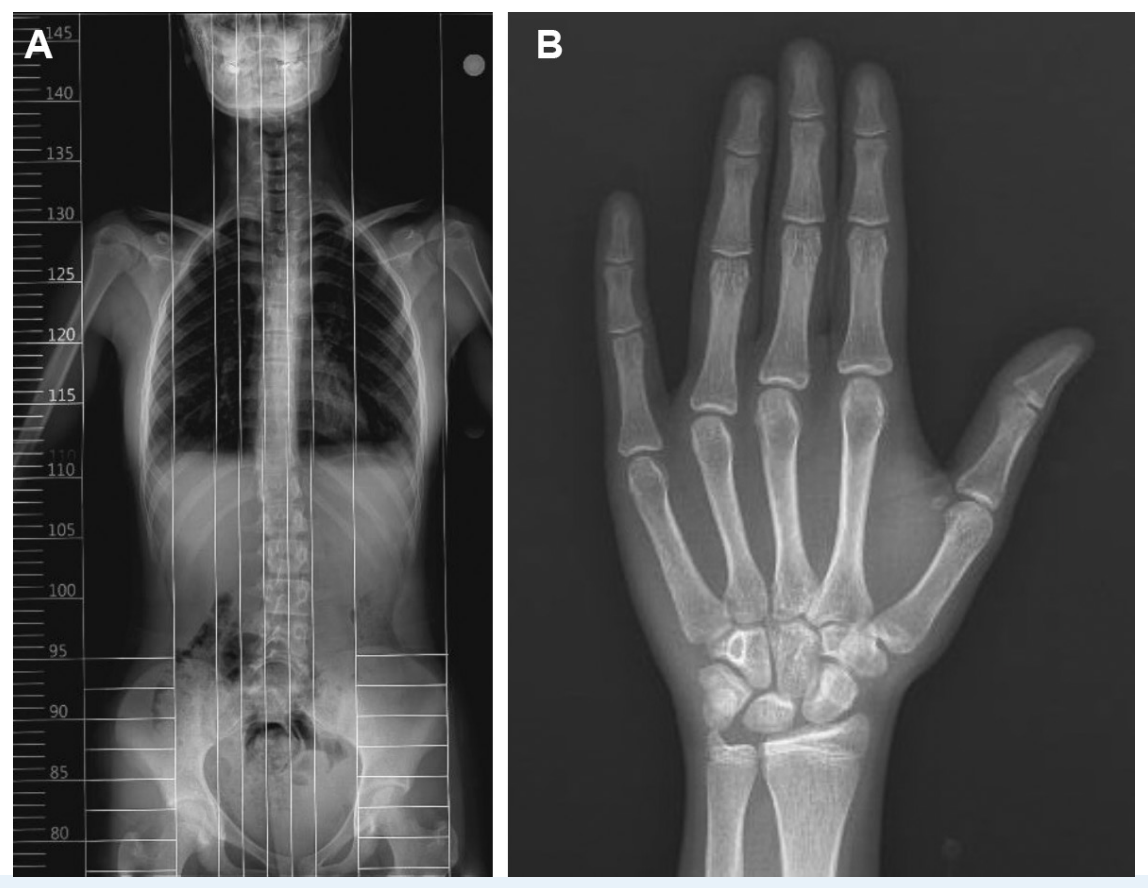

Figure $1 \mathrm{~A}, \mathrm{~B}$. Example of skeletal maturity mismatch between RS and SC: Risser 1 corresponding to Sanders 7

\section{RESULTS}

The sample size of patients included in the study provided a sampling power of 0.90. A total of 205 [126 (75.9\%) females and 76 (24.1\%) males] participants were included. The mean age was $13.81 \pm 1.85$ years. The demographic characteristics of the participants WAS detailed in Table 2.

The rate of incorrect staging was $17.3 \%$ between the Risser sign and Sanders classification stages. Age, height, weight,
$\mathrm{BMI}$, major curve angle, and apex location of the major curve were not associated with the miscorrelation of the Risser sign and Sanders classification stages. Females were at a higher risk of Risser sign and Sanders classification stage miscorrelation than males (17.3\% vs. 9.6\%; $p<0.05$ ). In addition, patients who did not have their first menarche had a higher risk for miscorrelation of Risser sign and Sanders classification stage $(36.1 \%, 19.1 \%$ vs. $18.6 \%$; $\mathrm{p}<0.05)$. 

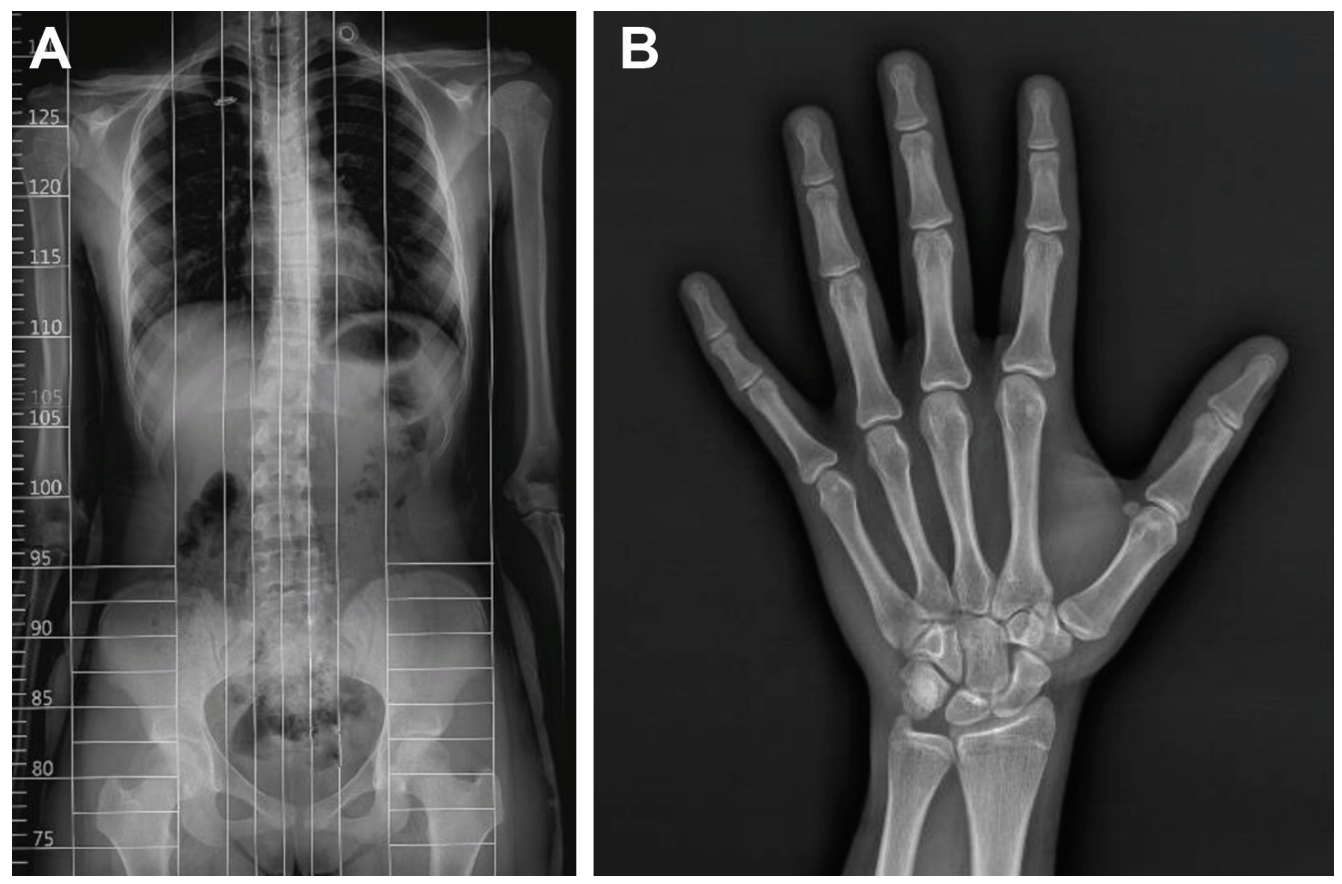

Figure 2A, B. Example of skeletal maturity match between RS and SC: Risser 4 corresponding to Sanders 7

Table 2. The demographic characteristics of the participants

\begin{tabular}{|c|c|c|c|c|}
\hline & & & n (\%) & Mean \pm SD \\
\hline Age & & & & $13.81 \pm 1.85$ \\
\hline Gender & Fema & & $126(75.9 \%)$ & \\
\hline vemaer & Male & & 79 (24.1\%) & \\
\hline Height (cm) & & & & $161.97 \pm 10.47$ \\
\hline Weight (kg) & & & & $51.77 \pm 11.42$ \\
\hline BMI & & & & $19.55 \pm 3.03$ \\
\hline & & $<18.5$ & $41(20.1 \%)$ & \\
\hline BMI & & $18.5-24.9$ & 135 (65.8\%) & \\
\hline & & $>25$ & $29(14.1 \%)$ & \\
\hline & & None & 72 (35.1\%) & \\
\hline Menarche & & $\begin{array}{l}\text { Last } 12 \\
\text { month }\end{array}$ & $68(33.1 \%)$ & \\
\hline & & $>12$ ay & 65 (31.7\%) & \\
\hline Major cobb & & & & $23.91 \pm 11.42$ \\
\hline Apex & $\begin{array}{l}\text { Thor } \\
\text { (T1-T }\end{array}$ & ic vertebrae & $91(44.3 \%)$ & \\
\hline $\begin{array}{l}\text { location of } \\
\text { the major }\end{array}$ & $\begin{array}{l}\text { Thor } \\
\text { junct }\end{array}$ & $\begin{array}{l}\text { olumbar } \\
\text { n (Tll-Ll) }\end{array}$ & 51 (24.8\%) & \\
\hline curve & $\begin{array}{l}\text { Lumb } \\
\text { verte }\end{array}$ & $r(L 2-5)$ & $63(30.8 \%)$ & \\
\hline
\end{tabular}

Interobserver correlations were determined as a substantial correlation for the Risser sign and an almost perfect correlation for Sanders classification (Risser $K=0.76$, Sanders $K=0.93$ ). In addition, the interobserver correlation of the Major Cobb angle was almost perfect $(K=0.89)$.

\section{DISCUSSION}

Our study reported a statistically significant difference between the two-growth maturation classification system that may occur in the false prediction of the treatment of the AIS patients.

Each classification developed to determine growth potential has its shortcomings. Risser sign ${ }^{(5)}$, one of the first classifications, is still widely used in planning followup and treatment of AIS ${ }^{(9)}$. However, it also has serious limitations. First, it cannot distinguish the vast area of skeletal immaturity, consisting of periods before, during, and after peak growth velocity. Second, patients at each stage presumably have a different risk for curve progression $(10,11)$. Other shortcomings include that the Risser sign stage may change depending on the direction of the radiological image taken (anterior-posterior or posterior-anterior) ${ }^{(12)}$ and differs between Europe and America ${ }^{(13,14)}$. The most important shortcoming of the Sanders classification is a longer learning curve ${ }^{(8,15)}$. 
When we considered studies evaluating the interobserver correlation between the Risser sign and Sanders classification in patients with AIS, Vira et al. ${ }^{\left({ }^{8}\right)}$ reported that both classifications had a moderate level of interobserver correlation and that the Sanders classification was more reliable. While Hammond et al. (16) reported that the interobserver correlation of the Risser sign was moderate, Sanders et al. ${ }^{\left({ }^{6}\right)}$ reported that the interobserver correlation of the Sanders classification they developed was considerably high. In all studies on the major Cobb angle, it was reported that the interobserver correlation is at a very high level ${ }^{(17-20)}$. Our study reported that our interobserver correlation was high, and our outcomes were accurate and are consistent with the literature.

There is a study in the literature that evaluates the correlation between the Risser sign and Sanders classifications. In their study, Minkara et al. (7) evaluated 165 patients with AIS. They were followed up non-surgically and showed that the male sex was in the risk group in correlation between classifications. Notably, our study showed that the risk group for correlation between Risser sign and Sanders classification was not the same.

Many studies in the literature have determined that the degree of the curvature at the time of diagnosis. Female sex, localization of the curvature (double curves and thoracic curve) ${ }^{221,22)}$ pre-menarche period, excess growth potential, and low skeletal maturation are risk factors in terms of the progression of the curvature ${ }^{(15,23,24)}$. In our study, the female sex and the pre-menarche period were risk factors in misinterpretation, indicating that more care should be taken in evaluating this patient group.

\section{Study Limitations}

There are some limitations to our study. First, this study was retrospective in nature. Although experienced evaluators were included in the study, the difference in experience could affect the results. Another limitation was that no control group was included in the study; however, this is not possible in practice.

\section{CONCLUSION}

Despite the miscorrelation of the growth potential classification system, evaluating more parameters to determine the growth potential of the patients with AIS may provide better planning of the non-surgical treatment.

Ethics Committee Approval: It was approved by the institutional review board (IRB number: 2019/4408) and was performed incongruent with the ethical principles of the Declaration of Helsinki.

Informed Consent: After approval of the IRB, informed consent was obtained from the guardians of all participants.

Conflict of Interest: No conflict of interest was declared by the authors.

Financial Disclosure: The authors declared that this study received no financial support.

Etik Kurul Onayı: Kurumsal inceleme kurulu (IRB numarası: 2019/4408) tarafından onaylandı ve Helsinki Bildirgesi'nin etik ilkelerine uygun olarak yapıldı.

Hasta Onayı: IRB'nin onayından sonra, tüm katılımcıların velilerinden bilgilendirilmiş onam alındı.

Çıkar Çatıșması: Yazarlar tarafından çıkar çatışması bildirilmemiştir.

Finansal Destek: Yazarlar tarafından finansal destek almadıkları bildirilmiştir.

\section{REFERENCES}

1. Li DT, Cui JJ, DeVries S, Nicholson AD, Li E, Petit L, et al. Humeral head ossification predicts peak height velocity timing and percentage of growth remaining in children. J Pediatr Orthop. 2018;38:e546. https:// doi.org/10.1097/BP0.0000000000001232

2. Dolan LA, Weinstein SL. Surgical rates after observation and bracing for adolescent idiopathic scoliosis: an evidence-based review. Spine (Phila Pa 1976) 2007;32:S91-100. doi: 10.1097/BRS.0b013e318134ead9

3. Little DG, Song KM, Katz D, Herring JA. Relationship of Peak Height Velocity to Other Maturity Indicators in Idiopathic Scoliosis in Girls". JBJS. 2000;82:685-93 doi: 10.2106/00004623-200005000-00009

4. Dimeglio A, Canavese F. Progression or not progression? How to deal with adolescent idiopathic scoliosis during puberty. J Child Orthop. 2013;7:43-9. doi: 10.1007/s11832-012-0463-6

5. RISSER JC. The Iliac Apophysis: An Invaluable Sign in the Management of Scoliosis. A Publ Assoc Bone Jt Surg I CORR ${ }^{\circledR}$. 1958;11. Avaliable from: https://journals.lww.com/clinorthop/Citation/1958/01110/The_Iliac_ Apophysis_AnInvaluable_Sign_in_the.14.as

6. Sanders JO, Khoury JG, Kishan S, Browne RH, Mooney JF 3rd, Arnold $K D$, et al. Predicting scoliosis progression from skeletal maturity: a simplified classification during adolescence. J Bone Joint Surg Am. 2008;90:540-53. doi: 10.2106/JBJS.G.00004.

7. Minkara A, Bainton N, Tanaka M, Kung J, DeAllie C, Khaleel A, et al. High risk of mismatch between sanders and risser staging in adolescent Idiopathic scoliosis: are we guiding treatment using the wrong classification? J Pediatr Orthop. 2020;40:60-4. doi: 10.1097/ BP0.0000000000001135.

8. Vira S, Husain Q, Jalai C, Paul J, Poorman GW, Poorman C, et al. The interobserver and intraobserver reliability of the Sanders classification versus the Risser stage. J Pediatr Orthop. 2017;37:e246-9. doi: 10.1097/ BP0.0000000000000891.

9. Lenke LG, Betz RR, Harms J, Bridwell KH, Clements DH, Lowe TG, et al. Adolescent Idiopathic scoliosis : a new classification to determine extent of spinal arthrodesis. JBJS. 2001;83:1169-81. Avaliable from: http:// www.ejbjs.org/cgi/content/abstract/83/8/1169 
10. Karol LA, Johnston 2nd CE, Browne RH, Madison M. Progression of the curve in boys who have idiopathic scoliosis. JBJS. 1993;75:1804-10. doi: 10.2106/00004623-199312000-00010

11. Little DG, Sussman MD. The Risser sign: a critical analysis. J Pediatr Orthop. 1994;14:569-75. doi: 10.1097/01241398-199409000-00003.

12. Noordeen $\mathrm{MHH}$, Haddad FS, Edgar MA, Pringle J. Spinal growth and a histologic evaluation of the Risser grade in idiopathic scoliosis. Spine (Phila Pa 1976). 1999;24:535-8. doi: 10.1097/00007632-19990315000006

13. Izumi Y. The accuracy of Risser staging. Spine (Phila Pa 1976). 1995;20:1868-71. doi: 10.1097/00007632-199509000-00004

14. Nault M-L, Parent S, Phan P, Roy-Beaudry M, Labelle H, Rivard M. A modified Risser grading system predicts the curve acceleration phase of female adolescent idiopathic scoliosis. JBJS. 2010;92:1073-81. doi: 10.2106/JBJS.H.01759

15. Sitoula P, Verma K, Holmes L, Gabos PG, Sanders JO, Yorgova P, et al. Prediction of curve progression in idiopathic scoliosis. Spine (Phila Pa 1976). 2015;40:1006-13. doi: 10.1097/BRS.0000000000000952.

16. Hammond KE, Dierckman BD, Burnworth L, Meehan PL, Oswald TS. Inter-observer and intra-observer reliability of the Risser sign in a metropolitan scoliosis screening program. J Pediatr Orthop. 2011;31:e80-4. doi: 10.1097/BP0.0b013e318236blc9

17. Kuklo TR, Potter BK, Polly Jr DW, O'Brien MF, Schroeder TM, Lenke LG. Reliability analysis for manual adolescent idiopathic scoliosis measurements. Spine (Phila Pa 1976). 2005;30:444-54. doi: 10.1097/01. brs.0000153702.99342.9c
18. Tanure MC, Pinheiro AP, Oliveira AS. Reliability assessment of Cobb angle measurements using manual and digital methods. Spine J. 2010;10:769-74. doi: 10.1016/j.spinee.2010.02.020

19. Zhang J, Lou E, Hill DL, Raso J V, Wang Y, Le LH, et al. Computer-aided assessment of scoliosis on posteroanterior radiographs. Med Biol Eng Comput. 2010;48:185-95. doi: 10.1007/s11517-009-0556-7

20. Wills BP, Auerbach JD, Zhu X, Caird MS, Horn BD, Flynn JM, et al. Comparison of Cobb angle measurement of scoliosis radiographs with preselected end vertebrae: traditional versus digital acquisition. Spine (Phila Pa 1976). 2007;32:98-105. doi: 10.1097/01.brs.0000251086.84420. $\mathrm{dl}$.

21. Lonstein JE, Carlson JM. The prediction of curve progression in untreated idiopathic scoliosis. J Bone Jt Surg. 1984;3:1061-71. Avaliable from: http://www.ejbjs.org/cgi/content/abstract/66/7/1061

22. Bunnell WP. The natural history of idiopathic scoliosis. Clin Orthop Relat Res. 1988;229:20-5. doi: 10.2106/00004623-199506000-00001.

23. Nachemson AL, Peterson L-E, Bradford DS, Burwell RG, Duhaime $M$, Edgar MA, et al. Effectiveness of treatment with a brace in girls who have adolescent idiopathic scoliosis. A prospective, controlled study based on data from the Brace Study of the Scoliosis Research Society. J Bone Jt Surgery-Series A. 1995;77:815-22. doi: 10.2106/00004623199506000-00001

24. Bunnell WP. The natural history of idiopathic scoliosis before skeletal maturity. Spine (Phila Pa 1976). 1986;11:773-6. doi: 10.1097/00007632198610000-00003 